\title{
ZADANIA RODZINY CHRZEŚCIJAŃSKIEJ W NAUCZANIU ŚW. JANA CHRYZOSTOMA
}

Problem azteristwa 1 rodziny, zawszo aktualny wo wszystkich epokach ${ }^{1}$, osiagnął azczególno znaczenie chrześcijaństio. I dzis c1eszy s1e wielkim zalnteresomaniem jako centralne zagadnienio nauczaniu kó́cielnym, dla którego podstame obok źródez biblifnych, gtanowla źódia patrystyczne. Pundamentalne znaczento tu Liot ám. Paria do Efezjan $/ 5,32 /$. Mazzeństwo traktujo on jako wiolka tajemnice "Chrystusie 1 Kośc1elo, dajac zarysie pokng juz teologie mazzeristwa jako Bozej Instytucj1. Ten Pawlowy tokst stal ate przod-

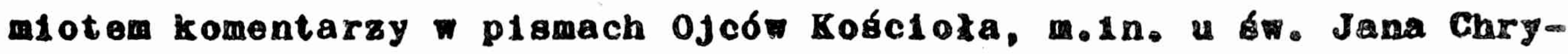
zostoma, zwlaszcza w Jego 20. homilil na List do Erezjan.

Jan Chryzostom z wielka precyzja przedetaia owoje máli na temat małzeństwa 1 rodziny, często yblogajac daleko naprzód, gźón1e - najwazniejszym temacie sakramentalnej milócl agazorikiej. która powinna byé realizowana według woro miłóscl Chrystusa 1 Kośc101a.

W taanym jednak spośró swolch bardzo $11 \mathrm{cznych}$ dz101/ponad 300/ Chryzostom nie zajmuje sie wyzacznie ani maldeństwam, and rodz1na. W rónych miejscach swolch kazań, częto pojodyncaych ada. niach, daje bogate niekledy sformulowania na temat chrzésoljángkioj rodziny.

Luźne wypowiedzi Chryzostoma o mażońtwie zebral 1 opracowal - syntetycznej caloscl Kyriakos Tsouros ${ }^{2}$. N1e ma natomast polnego opracowania na temat rodziny chrzośdjadakiej 1 jes gadar naucza-

1 Por. K.Tsouros, La dottrina sul matrimonio in San Giovann Criaostomo, "Aspernas" 21/1974/5: "Spocialmente ogg1, che 11 Ionomono della famiglia discorde o ribelle, aggrava 1 mali di guosta nostra travagliata societa, 11 pensiero del Crisostomo sul natrimonio o ut111881mo o di grande necessitä.

2 Tsour08, art, cyt., 5-46. Por. J.Dumortier, Le war1age dans 108 mllieux chrét1ens d'Antloche et de Byzance d'apres saint Jean Chrysostome, "Lettres d'humant té" 6/1947/ 102-166. 
alu św. Jana Chryzostoma. Nloktóre asporty tego zagadnienta zosta-

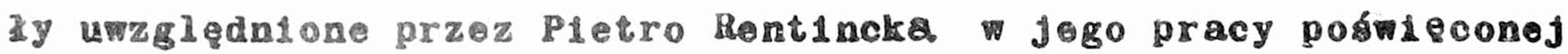

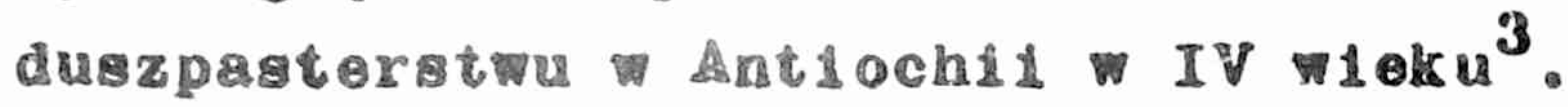

Prodmlotem togo artykuzu, który nawiazujo do rozpramy Rent1ncka, Jost ayntetyczno przedstaw 1onlo nauks śm.Jana Chryzosto-

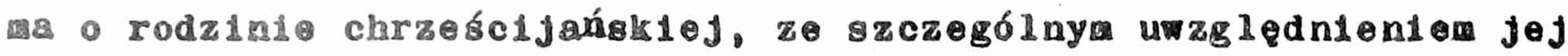

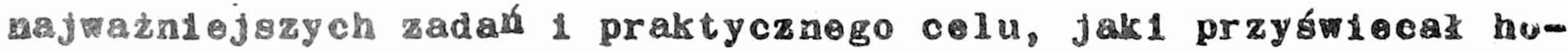
m11lom Antocheńczyka. Anal1za l ocona tak bogatogo eateriazu trós clowogo z wypowiedzi Jana Chryzostome moglaby 1 powlana byé uwzgledniona spocjalnym, obszerny opracowanic.

Istotnymi zadaniand rodziny wodlug nauki Chryzostomes: prokragcja 1 mychowante dzleci oraz majema pomoc malzonkón 1 pozostalych czlonkóm rodzing.

P r o r a a ja. Rodzina jost źródzem zycla. Prokraacja

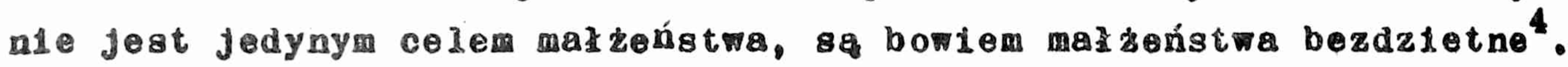

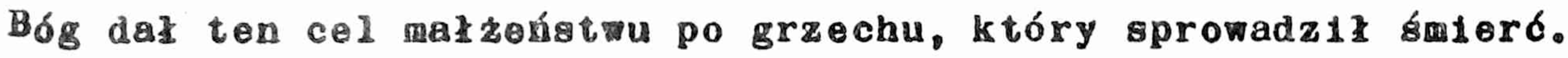

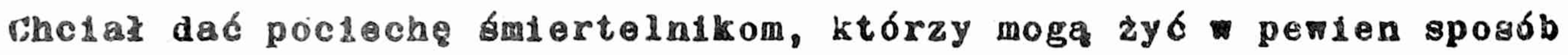
awolch dzloclach. Pragnaz toz ton sposób utrzymé przy zyclu

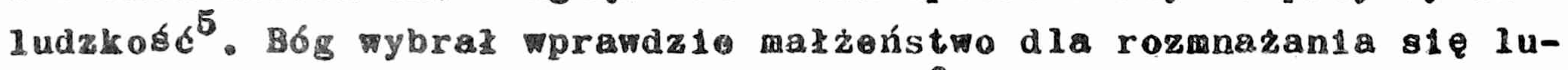
dz1. alo mógzby mybré takze inna droge 6 . W obecnym plante Bozym colam matzońtima jost zrodzenio potomstwa, jodnak nie zo swej natury, 210 z Bozego nakazu ${ }^{7}$. Makzeństwo we albo akt mazzorísk ma za cel zrodzenie potomstwa ${ }^{8}$. Pozadliwość nio jost dana dia grzochu, dla cudzolóstra albo dla rozpusty, locz dia zrodzenta dz10$\mathrm{cl}^{9}$.

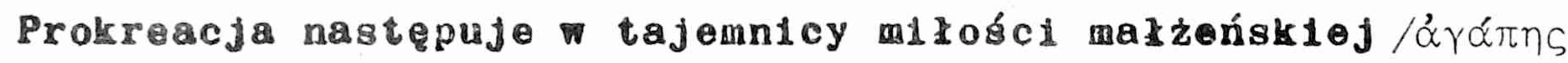

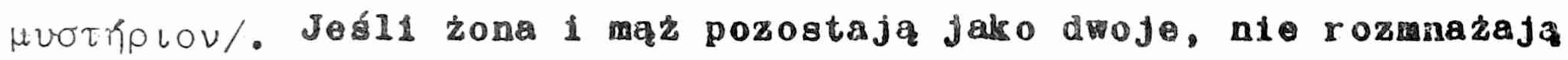

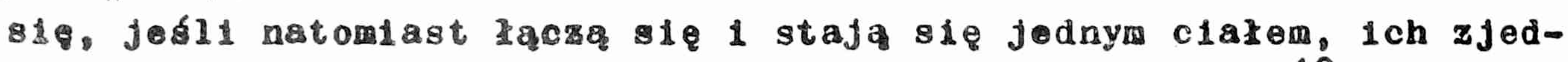

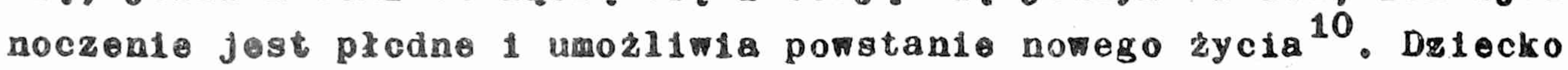

3 PoRentinck, La cura pastorale in Ant1ochia nel IV socolo, Homa $1970,251-280$.

4 In 111ud: "Propter pornicationes uxorem" 1,3, PG 51,213.

5 In Joannem hos: 19,1, PG 59,120.

6 Jak wypacku stworzenta Adama 1 Ewy oraz anlołb.

7 In 11ud: "Propter fornicationes uxorem"1,3,PG 51,213.

8 In opistulam ad Colosgonses hom, 12,4, PG 62, 385.

9 In oplstuIs ad sphes10s hom. 2,3, PG 62,20; In epistulam ad Galatas 5, 3, PG 61,669.

10 In oplstulam ad Colossonses hom. 12,5, PG 62,387. 
jost od razu nlejako mostem miedzy rodzicami, pontowaz unacnia ich jednośc. Nie sq juz ond dmojgiem, ale trojgiem, a przy tym tworza

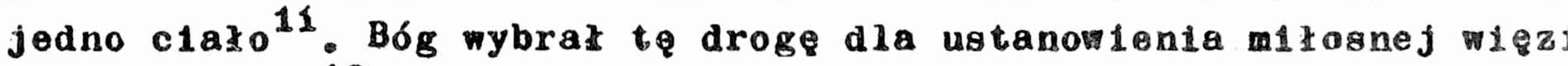
miedzy ludźmi 12 .

Dieci staja sie upragnionym bogactwem. Moda nezatka pragn10 tego bogactwa. Leka olo bardzo trwajej nioplodnó́cl ${ }^{13}$. Dzieci 8a mprawdzie przyczyng wilu srudnoscl i udrek zyolowych, jodnak brak dzieci stwarza jeszczo trudntejeza sytuacje 1 nie ma niczogo. bardzlej nteznó́nego dla mezczyzny l koblety niz brak potomstwa ${ }^{14}$.

Oprócz lęu przed bezpłodnościa, serce mzodej agzatki wstepuje tez lek przod zbyt licznym potomstwem ${ }^{15}$. Unikante dzieci

1 stosomani otody procuratio abortus jost juz znane w IV Chryzostom wsponina o tej praktyce, stosowanoj przoz tych, który chca pozbyó 81 dzlecka poczetego oudzolóstwio. Jan potopia to naduzycte jako grzoch clezszy od morderstwa, bo tono matki, które jest źródzem zycla, zostaje zamientono na lejsco anjerci ${ }^{16}$.

Zadanio rodzicóm wobeo dziocl nie ogranicza ale do samed tyl ko prokreacj1, ale trwa dalej wychomaniu dzloc1. N1e mago plodzenie dzieci czyni méczyzne ojcem, ale takze dobre wychowale. Nie rodzento dzieci czyni kobiete matka, alo dobre wychowanie ${ }^{17}$. y c ho w a 1 o. Hodzina - "szkola" domowa. Szkoka nie jest jednak czynnikiem decydujacym wychowaniu. Jest nim frodo-

11 Tamze, PG 62, 388.

12 In epistulam I ad Corinthios hom. 34,3, PG 61,289.

13 De sacerdotio III 17, PG 48,657, POK 23,75.

14 Ad Theodorum 1apsum II 5, PG 47,314, PSP 13,236; De Anna sormo $2,1, P G 54,644$.

15 De virginitate 57,4, PG 48, 577-579, SCh 125,306-310。

16 In epistulam ad Romanos hom. 24,4, PG 60,626; In Matthaeum hom. 28,5 , PG 57,357, tłum.J.Krystyniack1/Jana Chryzostoma wykad ewangelil ś. Mateusza w 90 homillach zawarty, Lwów 19032. t. $1-3 /$, t. 2,39 .

De Anna sormo 1,3, PG 54, 636-637. 
-18ko, Jakim dziecko wzrasta, a mianowicie: rodzina, słuzba domowa 1 przyjaciele. Opiekunem dzlecka, przede wszystkim chłopca. w drodze miegdzy domem 1 szkola jost "pedagog". Od niego w duzym stopniu zalezy wychowanie religijno-moralne dziecka. Niewolnik jost przociez zawse najblizej dzlecka speiniantu swej funkcji. Rodzice powinni starannie dokonywać wyboru pedagoga dla swoich dz1001, poniewaz "nie ma wazniejszej sztuk1 nad wychowan1e", a wychowanie "zajmuje sie kierownictwem duchowym, kształceniem umysłu 1 udoskonalentem charakteru młodzieńca ${ }^{18}$. Dzieciom potrzeba bieglego pedagoga, który by umial pokierowác lch rozwojem zakresie cnoty ${ }^{19}$. Jan Chryzostom zaleca rodz1com posylac swojo dzieo1, na powien przynajeniej czas, do mnichów na wychowanie religifne. Podobnio tez Anna powiorzyza swogo ayna Samuela Panu ${ }^{20}$. Apel ten jednak nie spotkal sie z powszechnym odzewem. W przygotowaniu do zyc1a obywatelskiego konieczna była takzo szkola. Tylko niekt6rzy mio= azleńcy chodzili do mnichów, Jak Jan Chryzostom 1 jego przyjaciele. Byll bowlem zdecydowant pośriecté sie na słuźbe Bogu 21.

Cały ciezar odpowiedzlalnośc1 za wychowante dzioci spoczywa więc przode wozystkim na rodzicach. Swiadcza o tym czerte zachety wow11ach Chryzostoma, skierowane do wiernych 1 wayajace $1 \mathrm{ch}$ do epelnianja tego obowlązu. Klasycznym tego przykładem jest 27 ho-1118 lub oklogao wychomantu dz10c122. To bardzo plekna przeciez

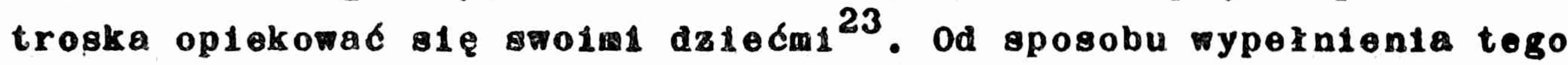
zadanta zalezy wiolka nagroda lub clezka kara, zbawienio albo pote-

18 In Mat thaeum hom. 59,7, PG 58,584, Krystyniack $1.3,18 ;$ in op 1stulam I ad Timotheum hom. $9,2, P G 62,546$, tzum. T.Sinko/Sw. Jan Zkotousty. Homsle na listy pastersk1e sw. Pawla 1 na list do F1lemona, Krakóm 1949/99.

19 In Mathaeum hom. 35,4, PG 57,11; 55,1, PG 58,542, Krystyniack1 t.2. 1181 312; Advorsus Judaeos 2,2, PG 48, 860; In Gonesim hom. 4,2, PG 54, 596 .

20 Adversus oppugnatores vitae monasticae III $12,20,3,18$, PG 47 , $368,383,351,380$.

21 Ad Thoodorum lapsum II 1, PG 47, 309, PSP 13,231.

22 Ecloga de liberorum educat1one, $P G$ 63,763-772; por. Tsouros, art.cyt., 46 .

23 In epistulam I ad Timothoum hom, 9,2, PG 62,546, Sinko 99. 
p1en1e:
"0jcow10, słuchajcio tego: wychowujc10 swo1ch gynów w karności; wielka gorliwościa upominajele toh
- Imie Panán /ET 6,4/24.

Fychowanio dz1ec1 przystuguje rodzicon prama naturalnogo. Wiezy krw1, uozucia 1 naturalna zaleznó́ć dzlecl daja rodzlcom moznośc przeprowadzenta dobrego wychowania od samego poozatku, od plorwezych lat $^{25}$. Dlatego samo przekazanio zycia 1 zrodzenio potomstwa nio mystarcza, zeby mozna byto nazywać sie rodzicami. Nio wystarcza róniez naturalne uczucie. Potrzeba ustawicznej troski 1 clagiej opleki nad dzieckiem. Na tym polega chrzécijańskie porozanie rodzicow. Zaniedbanio tego zadania byłoby grzechem ciezk1m26. Rodz1ce sa odpowiedzialni takze za grzechy swolch dzieci. otrzymaja c1ezka kare, podobnie jak najpyzazy kapłan Hel1, który by zbyt poblazliwy dla swolch synóm 27 .

ojclec jako glowa rodziny pierwszy ponosi clezar odpowiodzialności za wychowanie.

\footnotetext{
"Jestes nauczycielem 1 wychowawce cazego twojego domu. Tobie przede wozystkim Bbg polecil stale pouczad zone 1 dzleci" 28 .
}

Dlatego nakaz wychowan1a tylko częsclowo odnosi s18 do matk1, poniewaz one atale przebywa z dzlecml $w$ domu $^{29}$.

24. In principium Actorum hom. 4,3, PG 51, 100-101; In Matthaeum ho⿴囗 77,6, PG 58,709-710, Krystynlack1 t.3,206; In 111ud: "Vidua eligatur" 9, PG 51,329.

25 Advorgus oppugnatores v1tae monasticae III 4,11, PG 47,354, 366: In epistulam ad Titum hom. 2,1, PG 62,672, S1nko 318.

26 Adversus oppugnatores vitae monast1cae III 3 , PG 47,351

27 Advorsus oppugnatores v1tao monasticae III $3,7,21$, PG 47,352, 359, 385; In ep18tulam I ad Timotheum hom, 9,2, PG 62,546. Si nko 99; In 111ud: "Vidua el1gatur" 8, PG 51,329.

28 In 11lud: "V1dua oligatur" 9, PG 51,329.

29 De Anna sermo 1,4, PG 54,638. 
Troska o wychowante dz10c1 nie jest latwa. Wymaga ustamicznego madzoru 1 czujnósel. Dlatego nie mytarczy zapewnié dziociom tylko chlob 1 mgystko, co ma z nim zwiazek. N1o wystarczy toz dać im odpowlednle wyksztalcenio, aby radzliy sobio zyclu. Obowizzkion

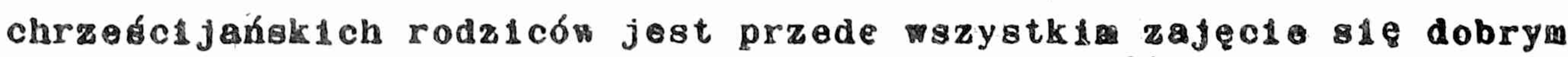
wychomanlom moralnym 1 religh jnym swotch daloci ${ }^{30}$.

Czlowek ze swej natury nie jest dobry. Wec 1 modzlez jest. bardzloj skzonna do zlogo niz do dobrego 31 . Sama z sleble nie jest zdolna dojéć do cnoty ${ }^{32}$. Dlatogo trzeba zaczynác od samej młodoścl mykorzentac wady 1 zaslewać cnoty, kledy dzieci saj jeszczo wrazliwo 1 podatne na wplyw wychowawczy33. Nio wolno z tym zwlokad. Nawet maze dzlect trzeba przyzwyczajac od samogo początku do unikania wad 1 zachecac do szlachetnego postepowania. Potem beda to robic z przyzwyczajenia ${ }^{34}$.

Pontewaz dzieci nie sa skionne ze swej strony do dobrego, rodzlce 1ęc powinni nakazac im wáclwo postepowante, nawet wbrew 1ch wol1, a niekledy nawet siza, np. przez usuniecte ich od stołu, mymierzente chłosty, zawstydzenie 1 uzycie innych, podobnych surowych środkó ${ }^{35}$. Nie mystarczy jednak samo udzielanie napomnień. Trzeba takzo postraszyé dzleci z cała surowościa, mając na uwadzo ich

30 In 11lud: "Vidua eligatur" 7, PG 51,327; Adversus oppugnatores vitae monasticae III 5,8, PG 47,357,363; In epistulam ad Ephesios hom. 21,2, PG 62,151; In epistulam I ad Timothoum hom. 14,1, PG 62,572 , Sinko 142-143.

31 In Genesim hom. 59,1, PG 54,515; por. In epistulain. I ad Timothoum hom. 9,2, PG 62,546, Sinko 99 .

32 Advergus oppugnatores vitae monasticae III 6, PG 47,358.

33 Tamze III 4,18, PG 47,356,379; In epistulam ad Éphesios hom. $21,1, P G 62,150$.

34 In epistulam I ad Timotheum hom. 9,2, PG 62,546, Sinko 99;

In Joannem hom. 3,1, PG 59,37; In epistulam ad Ephesios hom. 21,1, PG 62, 149; In epistulam ad Titum hom. 2,1, PG 62,672, Sinko 318 .

35 Ad populum Antiochenum hom. 7,3, PG 49,94. 
poprawę ${ }^{36}$. Chryzostom zachęca jednak rodziców przy tym do umiaru wymierzantu kar: dzlecko powinno bad sie kary plzycznej, ale nle wolno nia poszugiwać sie zbyt często, tylko wtedy jedynie, jeśli to jest bezwgleqdnie konieczne 37 .

Jeszcze waznlejgzym srodklem wychowawczym od upominanta 1 kar cenia jest dobry przykład rodzicóm. Jesil rodzice zyja trzezwosci 1 postępuja szlachetnle, dzloci moga naśladować ich przykład: "kiody korzeń jest dobry, rozwjaja sie takze galazk1"38.

Szczególną uwage zwraca Chryzostom na cnotę czystóci ${ }^{39}$. Troska - nla jest potrzebna juz tedy, kiedy dzleci sa jeszcze małe. Trzeba trzymat je z dala od kazdej zepsutej moralnio osoby, zwaszcza powstrzymywać od teatru 40 . Nie ma wady bardzioj pociagajacej dia miodziezy jak nieczystó́ć, dla przokonania młodych 1 namónienia $1 \mathrm{ch}$ do cnoty czystośc1 nie ma innego bardzlej skutecznego środka niz grozenio im karą piekta 1 .

Wychowanie dziowcząt jest szczególnym zadaniem matki, która jest zawsze blisko córk1 domu 1 powinna ją wychować swoja skromnością, unikaniem każdego zbytku 1 przesadnej miękośc1, trzymaniem jej $\mathrm{w}$ domu:

Matk1, przygotujoie dobrze smoje córk1 do zyc1a w mazzeństwiel Troska o to jest dla was zatwa. Czurajcie, aby pozostawazy w domu. Przedo wsystkim zaśs wychowujcie je wobozności, zeby były szlachetne 1 gardzizy pieniadzem, aby nie troszczyly sie zbytnio o plolegnacje swej urody 1 o stroje. Tak przygotomane mydajcie je za mat" 42 .

36 In 111ud Isalae: "Ego Dominus" 6, PG 56,151; In Matthaeum hom. 35, 4 , PG 57, 11, Krystyntack1 t.2, 118; De verb1s Aposto11: "Habentes oundem Sp1ritum" 2,6, PG 51,286; In 111ud: "Vidua -11gatur 8, PG 51,329; In Genesim hom. 59,5, PG 54,519; In op1stulam ad Philemonem hom. 3,2, PG 62,718.

37 In 111ud: "V1dua el1gatur" 10, PG 51,330.

38 In opistulam I ad Timotheum how. 9,2, PG 62,548, Sinko 99; Adversus oppugnatores v1tae monasticae III 4, PG 47,356; In 111ud: "Vldua ol1gatur" 10, PG 51,330; In opistulam ad Ephesios hom. 21,2, PG 62,151.

39 De Anna sermo 1,6 12,6, PG 54,642 1 652; In Genesim hom, 59,3, PG 54,517; In epistulam I ad Tmotheum hom, 9,2, PG 62,546, S1nko 99 .

40 De Inani gloria et puerorum educatione 56, SCh 188,154, PSP $13,175$. 41 Tamz 76, jCh 188,178, PSP 13,181. 
Oprócz wychowanta moralnego, rodzlce sa równiez odpowiedz1alni za plerwsze pouczente swolch dzieci wakresie religi14. Takzo z tym wychowaniem trzeba zaczynac od lat najmłodszych ${ }^{4}$. Nalezy ezczogólnie zatroszczyć sie o mychowanio biblijne dzieci,pouczać je o Pló-

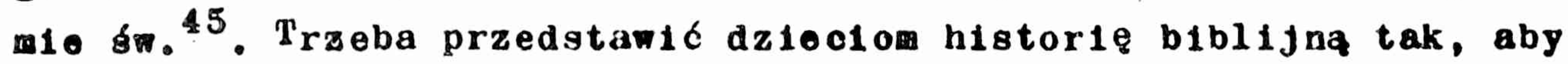
to malońtia mogyy Ja zrozumiec. Trzeba powtarzać te same opowia-

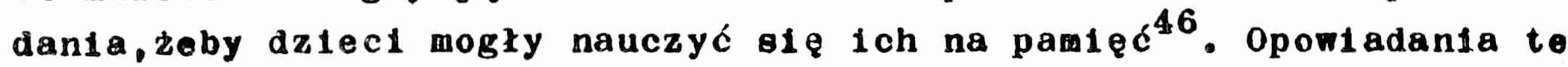
trzeba doblerać roztropnio, dostosorująe je do ograniczonych mozl1wośc1 poznawczych dzlecka. Chryzostom np. proponuje, aby zaczynac mówić o piekle dzieciom w wieku ok. 5 lat, jeszcze później, wieku ok. 10 lat, można opowiedzieć historie potopu, Sodomy 1 Egiptu 47.

Tyro samym czasie nalezy przyznyczajac dziecl do praktyk rel1gljnych, np. do postu we frody 1 piatk188. Rodzlee pokazuja dzieciom, jak 818 robi znak krzyca 1 nakazuja im mówié pierwsze wodlitwy. Splewaja tez razem swolm dzlociom psalmy w domu 1 pieśni religijne 49. Rodzice maja tez obowizzek towarzyszenia dzlecion do kościoja, takzo wtedy, kiedy nie wykazuja one zbyt wielkiej checl, aby sie tam udać,

42 In epistulam I ad Timotheum hom, 9,2, PG 62, 547; por. Quales ducendae sint uxores 3,9, PG 52,239; In epistulam ad Colossenses hom. 10,5, PG 62,374; De sacerdotio I, 2, PG 48,625, POK 23,4 .

43 In epistulam I ad Timotheum hom. 9,2, PG 62,564, Sinko 99.

44 De Inan1 glorla et puerorum educatione 18, $\operatorname{SCh} 188,100-102$, PSP 13, 163-164.

45 De Anna sermo 3,4, PG 54, 658; De Inan1 gloria 39, SCh 188,130, PSP 13, 169.

46 De inani glorta 39, SCh 188,130, PSP 13,171.

47 Tamze 52, SCh 188,150, SCh 13,172.

48 Tamze 22, SCh 188,108, PSP $13,165$.

49 In epistulam I ad Corinth10s hom, 12,7, PG 61,106; In epistulam ad Colossenses hom. 9,2, PG 62,363. 
czasem trzeba je przymusié do tego, aby w ten sposób wytworzyé przyzwyczajenie 50 .

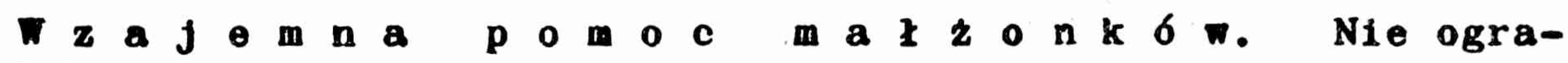
nioza sie ona tylko do cnoty czystósci, ale uwzglednia tez cale zyc1e mazzońskie. Człowiek jest z natury słaby 1 ograniczony. Małzoństwo jest po to, aby jedna strona mogka uzupełniac braki druglej strony 51 . Małzonkowie pomagaja sobie wzajemnio przez znoszenie ciezarón drugiej strony, aby wspólne pozyc1e małzeńskie uczynie mozliwym do znoszenia wszystkich przeciwnośc1 ${ }^{52}$.

Małzonkowie powinni pomagać sobie szczególnie w dązeniu do doskonałośc1. Ich wspólny dom powinten być "palestrą" cnót, "szkozą" uświecenta, doskonałośc1 rodziców 1 zbawienıa całej rodziny. Żona 1 mazz maja sie zachęcać wajemnie do doskonalenia zycia chrześc1jańskiego 1 praktykowania cnot ${ }^{53}$. Mazz jako głowa zony, ma obowizzek pouczać swoja zonę wprawach odnoszzcych sie do doskonatości chrzescijańskiej 1 o sposobach praktykowania cnót. Winien to robić zviaszcza w pierwszym okresie małzeństwa, kiedy młoda zona ma jeszcze duzo szacunku dla męza 1 jest bardziej wrazliwa na jego upomnienia ${ }^{54} \mathrm{Ca}_{-}$ la homilie 20 na list do Efezjan, która zawiera podobne rady dla męza, określaj niektórzy uczeni jako "eln ganzes Gesetzbuch der christlichen Ehen ${ }^{55}$. Jeśl1 mazz jest pogodny, ma poczucie humoru, a przy tyı jest skromny, to zona odnosi z tego duzo korzyśc1, takzo dziecko56. Ten sam sposób zona moze pomagać swemu męzowi do warostu z nim cnoty swoim słowean 1 przykzadom ${ }^{57}$. Kiedy małzonkowie tak poucza-

50 In 11lud: "Si esurierit inimicus" 3, PG 51,176.

51 In Joannem hom. 19,1 PG 59,120.

52 In Genesim hom. 38,1, PG 53,350.

53 In Joannem hom. 47,5, PG 59,270; Por. Tsouros, art.oyt., 5.

54 In epistulam II ad Thessaloniconses hom: 5,5, Pa 62,499; Adversue Judaeos $2,3, P G 48,860$; In Mat thaoum hom. 30,5, PG 37,368, Krystyniacki t.2, 55; In epistulam ad Ephesios hom. 20,8, PG 62, 146.

55 Por. M.V1lier, K. Rahner, Aszese und Myst1k in der Veterzelt, Frolburg 1939, 284 nst. Jako "ein ganzes Gesetzbuch der christilchen Ehe".

56 In epistulam II ad Tessalonicenses hom, 3,4, PG 62,498.

57 In Joannem hom. 61,3, PG 59,340. 
Ja sle wajemnie 1 przebaczaja sobie, tworzy sie rodzina naprawde chrześcijanska 1 takio wopózzyole $\mathbf{m}$ miłoścl mozo trwać nawet po 自然 erc1 $^{58}$.

Mąz jest głowa rodziny 1 głowa takze zony, która winna mu jost posłuszeństwo 1 uległoś ${ }^{59}$. Tak1 porzadek jest zadany człoriekow przez Stwórce w oparciu o róznioe zachodząca między mężczyznq 1 kobleta, nie tak jednak, jakoby kobieta była z natury nizsza; jest to tylko róznica płci. Maz jest glowa, di nie tyranem. Nie wolno mu policzkowad albo maltretowac swojej zony, bo głowa, która traktuje ciało z pogardą, robi zle takto soble samej. Fyżzośc męza powinna wyrazać s1e.w szczerej miłoścl do zony ${ }^{60}$. Relacja miedzy mezzem 1 zona nie jest relacja miedzy panem 1 niewolnica. Zona jest towarzyszka zycia swego męza, powinna byé mu posłuszna 1 uległa nie ze strachu, lecz dobrowolnie, oposób wolny, z wasnego wyboru 1 m mitosc1a 61 .

lá́tnica płci nie powinna byé powodem do dumy ze strony mezczyzny, ant powodem deprecjacjt zony, pontewaz kazda płeć ma soble wiaśc1me runkcje, zgodnio z naturalnym porządkiom ustalonym przez Stwórce. Podzielil on te runkcje tak, ze męzczyzna pracuje poza domem 1 zajmuje sie spramami publicznymi, podczas gdy zona zajmuje sie spramami domowymi ${ }^{62}$. Kobleta nie moze zajmowac sie administracja spraw publicznych. Rónnie wazna przeciez jest jej funkcja $w$ domu, - którym nie moze jej zastąplé męzczyzna63. W ten sposób zona

1 maz maja obowlązek pomagac soble majemnie 1 jedno drugiemu słuzyc owoiml zdolnosciami ${ }^{64}$.

W tym uzupeznianiu sie mazzonkonie moga zyć w zgodzie, a wedy pogodna atmosfora w domu będzie ucieczka 1 portem pokoju, źródłem mszelkiego dobrá. Jan Chryzostom tak opisuje piekno zycia małzenisk1ego:

WW domu niech panuje 1 umacnia sie pokój. Zona niech będz1e oddana swemu męzow1, a mąz niech

58 In opistulam ad Ephesios hom, 20,5, PG 62,141.

59 In Genesim hom. 8,4, PG 53,73.

60 In epistulam ad Ephesios hom. 20,4, PG 62,140.

61 In epistulam ad Ephesios hom. 20,2, PG 62,137.

62 Epistola 170, PG 52, 709-710.

63 Quales ducendae sint uxores 3,4, PG 51,231.

64 In opistula I ad Corinthios hom: 34,4, PG $61,292$. 
ma mozliwośc ucieczk1 w swojej zonto od spraw zewnętrznych 1 niepokoj6w, jak do portu, gdz1e moze znaloźc pocioche $w$ kazdym kłopocie. Na to dana mu jest zona do pomocy, aby rozradowany jej zachęta, był zdolny oprzec sie mszelkiemu złu, któro mus1 znosic. I dlatego, kledy zona jest cnotliwa 1 spokojna, nie tylko umacnia swego męza swoim towarzystwem, lecz jest mu pozyteczna wielu innych sprawach. Robi wszystko dogodnym 1 katwym dla niego. Nie pozmala, zeby martwit sie zewnętrznymi trudnościami albo tyml, które powstaja kazdego dnia - domu. Dlatego, jak dobry zarzadca, zamienia 8woja mądroscia kazdy nlepokój ducha $w$ pogode 1 przynosi pocieche swoja wielka roztropnościa. C1, którzy zyja tak zjednoczent ze soba, nie odczumaja cięzaru trudnośc1. Dlatego, kiedy panuje taka zgoda 1 pokój, kiedy lstnieje wieź miłó́l miedzy zonz 1 męzem, wazystko obróc1 się na dobro, a on1 sam1 nie będa narazent na zasadzke, bo otoczoni sa jakby murem mocnym 1 nie do zdobycia, tj. zgoda redkug wol1 Bozeje65.

Pokój 1 zgodę między zoną 1 męzem trzeba wiecej cenić niz mszystko inne ${ }^{66}$. Miłośc małzenska nie jost tylko zewnętrzna. Taka miłóć oparta jedynie na pieknie zewnetrznym, nie trwa dłuzej niz jeden miesiac albo najdłuzej jeden rok. Polega ona przede wszystkim na wspólnocie zycia, na zjednoczeniu duchowym, wtórym zona 1 maz maja naprawde jednego ducha 1 sa jednym ciałem 67 . Zgodnie z maturalnym porządiem męzczyzna 1 kobleta sa stworzent wajemnie dla sioblo 1 zadna inna relacja miedzy nimi nie jest tak fundamentalna 1 konieczna ${ }^{68}$. Dlatego Jan Chryzostom zachęca maztonkón do stamiania wyzoj miłośc1 małzeńskiej nad każda Inna przyjaźn, do atawiania nyzej towarzystwa zony nad przebywanie razem z przyjaolółmi. Zamiast szukać rozrywki w teatrze, niech maź szuka szczęs$01 a \sim$ domu. $w$ towarzystwie zony ${ }^{68}$.

R O d z 1 n a m a $\mathbf{y}$ y $\mathbf{m}$ o

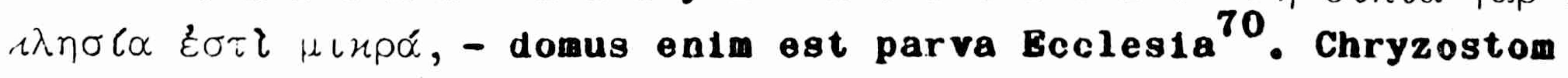
powtarza czesto to zdanie mazzonkom. Ojo1eo peini w domu runkcje

65 In Genosim hom. 38,7, PG 53,360.

66 In epistulam I ad Corinthios hom. 19,1 PG 61,153.

67 In Gensim hom. 45,2, PG 54,416.

68 In eplstulam ad Ephesios hom. 20,1 PG 62,135.

69 Tamte, 20,6, PG 62,143; In Mathaeum hom 37, 7, PG 5?,428, Krystyniaoki t.2, 142; In opistulan ad biphesios hom. 20,8, PG 62,147 .

70 In ep1stulam ad Ephesios hoin. 20,6, PG 62,143; In epistulam I ad Timotheum nom. 10,2, PG 62,549,Sinko 105. 
biskupa w trosce o szystkich swoich domownik6w. 0jciec rodziny, podobnie jak biskup, ma obowizzek pouczania swoich domowników - Bogu. Wiele razy zachęca Chryzostom męzczyzn do opuszczania koścloła 1 udawania sie bezpośrednio zaraz do domu, w celu zapoznania z treścia kazania swojej źony, dzleci 1 słuźby. Dom staje sie wtedy naprawdę kościołem. Rozlana jest nim laska Ducha Świętego. Panuje w nim pokój izgoda ${ }^{71}$.

Plerwsza troska małzonków powinno być umozliwiante wzrostu. w poboznośc1 słowem 1 przykładem oraz stmarzanie w domu atmosfory otwartej na sprawy Boze ${ }^{72}$. Dzleci natomiast powinny czcić rodzicón przez odwdzięczanie się im za troski 1 kłopoty, które rodzice podejmuja dla nich ${ }^{73}$. Kiedy wszyscy zyja tak zgodnie z nauka Boza 1 sa zjednoczeni węzłem miłośc1 1 wzajemnej słuzby, Chrystus jest w takim domu obeony razem z chórem an1ołor, 1 w ten sposób dom przekształca sie mały kościól ${ }^{74}$.

Dom staje sie takze kościołem, kiedy czyta sie w nim 1 rozwaza Pismo św. Lektura Bibli1 jest duchowym stołem domu, aby karmíc życie prowadzone według Ducha ${ }^{75}$. Podczas lektury historil biblijnej można podzimiac 1 chcieć násladować źycio świętych apostorón oraz zaprosić do swego domu 1 przyjąć gościnę świętych, nawet samego Pana $^{76}$.

Oprócz lektury Pisma św. trzeba także wspólnie oie modlić. Gdzie kilku jest zgromadzonych na modlitwie l śpiewantu psalmór, można nazwać to zgromadzente naprawde Kośc1ołem77. Chryzostom zaleca modlitwe 1 splewanie psalmów zwaszcza przy stole, przed 1 po obledzie. Psalmodia jest obrona przecimo zasadzom diabła 1 umozliwia obecnosc Chrystusa tak, ze dom staje sie kosciołem 78 .

71 In Genes1m hom. 6,2, PG 54,607.

72 In Mat thaeum hom. 77,6, $P G$ 58,709, Krystyniack1 $t .3,206-207$.

73 In Joannem hom. 85,2 PG 59,462.

74 In Genesim sermo 7,5, PG 54,616; 8,2, PG 54,620; In Mat thaeum hom. 48,7, PG 58,495, Krystyniacki t.2,243.

75 In Genesim hom. 6,6, PG 53,61; 10,8, PG 53,90; In Joannem hom. $32,3, P G 59,186$.

76 In epistulam ad Romanos hom. 30,4, PG 60,665.

77 Expositiones in Ps 41,2, PG 53,158; In Acta apostolorum hom. 26,4, PG 60,203.

78 Expositiones in Ps 41,2, PG 55,157; In ep1stulam ad Romanos 
Religijno ozdabianie domów prywatnych w starozytnyu chrześcijanstwio pozostawia wiele do zyczenia z punktu widzenia artystycznego, jak zaumaza Chryzostom. Podłogi wielktch palaców zdobla jeszcze mitologiczne motywy, czasem nawet nieprzyzwoite. Z druglej strony napisy chrzescijańskie znajduja sie takze na drzwiach 1 oknach prywatnych domów. Chryzostom wspomina o praktyce malowania znaku krzyza jako symbolu zwyclęstwa na áclanach 1 oknach domu ${ }^{79}$, ale ma tu na myśl1 przedstawlan1e ukrzyzowanego Chrystusa.

Miłośc rodzinie nie ograntcza się tylko do domowników, alo odnosi sie takze do Innych, przede wszystkim do służby, która mieszka w domu. Chryzostom nie występuje przeciwko zniesieniu instytucji niewolntetwa, chociaz otwierdza, ze Kośc16ł nie robi rónicy między niewolnikami 1 wolnymi, 1 ze takzo niewolnicy powołan1 sa do zbawionia ${ }^{80}$. Jeden raz p1ętnuje bogaczy, którzy kaza sobie towarzyszyc orszak owi słuzby, 1 ośliadcza, ze wystarczyłaby jedna do dwóch albo trzech osób ${ }^{81}$. Zachęca panów do traktowania po ludzku swojej słuzby 1 do nie przebierania miary $w$ karaniu ${ }^{82}$. Pan ma obowlazek pouczać szczególnte w zakresie nauki chrześcijańskiej swoją słuzbę tak, jakby naleźçcy do niej byl1 jego wasnymi dzleć$\mathrm{mi}^{83}$.

N1e tylko słuzba, ale wszyscy, takzo sąsiedz1, maja odnieść korzyść z dobrej rodziny chrześcijańskiej. Taka rodzina wywiera pozytywny wpływ na inne rodziny w swoim srodowisku. Zgoda $w$ domu jest niejako miłym zapachem, którym moga sie cieszyé wszyscy: sąsiedz1, przyjaciele, krewni, 1 znajom1, bo w przeciwnym razle wszystko sie wal1 1 upada ${ }^{84}$. Ten aspostolsk1 aspekt rodziny staje sie jesz-

hom. 24,3, PG 60,626; De Anna sermo 2,5, PG 54,650.

79 In Matthaoum hom. 54,4, PG 58,537, Krystyn1ack1 t. 2,304.

80 In epistulam ad Philemonem hom. 1,1, PG 62,705, Sinko 369; In epistulam I ad Corinthios hom。19,4, PG 61,156 .

81 In epistulam I ad Corinthios hom. 40,5, PG 61,353.

82 In epistulam ad Ephesios hom. 15,3, PG 62,109.

83 Tamze, hom. 22,2, PG 62,158; In eplstulan ad Colossenses hom. 10,1, PG 62,367; In eplstulam II ad Thessalonicenses hom. 5,5, PG 62,499.

84 In oplstulam ad Ephesios hom. 20,1, PG 62,136; 20,9, PG 62, 149. 
cze bardziej oczywisty, jesil dom jest otwarty dla biednych 1 podróznych, gdzie kwitnie goślnnośc, jak dom Pryski 1 Akw111/Rz 16,3-5/:

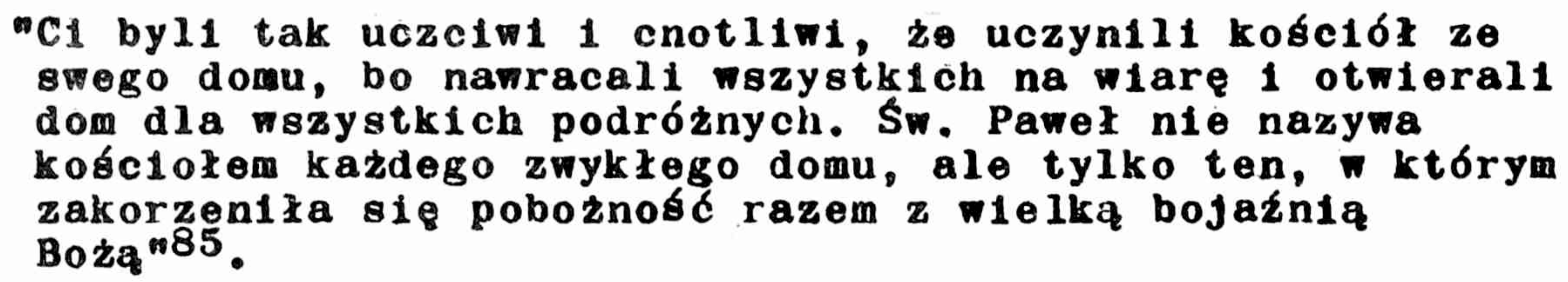

Rodzinny dom, który stał olę prawdziwym małym kościołem, z prawem gościnnośc1 dla biednych 1 plelgrzymów, podróznych 1 wędrowców, prześladowanych za prawdę 1 swe przekonania, wypędzanych nawet z własnej ojczyzny ${ }^{86}$, stale goszczacy Chrystusa doznajacego w ludziach bezinteresownej pomocy 1 solidarnośc1, to prawdziwy dom Bozy na ziemi.

Rodzina chrześcijańska, ze swyml lstotnymi zadaniami, przedstawionymi nauczaniu św.Jana Chryzostoma, 1 dzís moze budzić nie tylko szczególne zainteresowanie, ale 1 zachwyt, skoro przez rodz1nę prowadzi droga do postępu ludzkośc1.

K8. Henryk Wójtowicz - Lublin

DE OFFICIIS FAMILIAE CHRISTIANAE IN DOCTRINA S.JOANNIS CHRYSOSTOMI /Argumentum/

Auctor hulus particulae de familia christiana in doctrina sancti Ioannis Chrisostomi breviter vult soribere et imprimis responsum quaestioni dare, quomodo llla officia sua implere debeat. Maximl momenti in ramilia christlana habentur haec: et prolis procreat1o et liberorum educatio et adiutorium mutuum ab omnibus ferendum. Familia christiana cons vitae, schola domestica, palaestra omnium virtutum, locus, ubl sancti fiunt, in sermontbus Ioannis saepe nominatur. Domus christianorum, quae parva ecclesia etiam a Chrisostomo dicitur, et pauperibus et peregrinantibus aperta semper esse debet, ut hospitalitas in ea cum amicitia ot caritate omnibus in extrema necessitate degentibus libenter praebeatur. Per hanc familiam vero christianam via ad humanitatis progressum corta ducitur.

85 In epistulam ad Romanos hom. 30,3, PG 60,664; 24,3, PG 60,626; In epistulam ad Ephesios hom. 20,9, PG 62,147; por. P. Rentinck, art.cyt., 280.

86 In Genesim hom. 1,4, PG 54,585. 